\title{
Functional-technological properties of protein composite of animal origin
}

\author{
Natalia Povarova, Liudmyla Melnyk
}

Odesa National Academy of Food Technologies, Odesa, Ukraine

Keywords:

Meat

Protein

Poultry

Additives

Drying

\section{Article history:}

Received 23.06.2018

Received in revised

form 28.08.2018

Accepted 28.09.2018

\section{Corresponding author:}

Liudmyla Melnyk

E-mail:

meladka92net@

gmail.com

DOI: $10.24263 / 2304-$

974X-2018-7-3-9

\section{Abstract}

Introduction. The purpose of the study is to study the functional and technological properties of the obtained protein compositions from poultry meat and to determine the optimum with high quality indices.

Materials and methods. The meat of mechanical treatment, fillet of poultry, hams with skins were studied, which were subjected to microwave-vacuum drying with humidity not more than 5\% and prepared samples - Mepro 85 (the Dutch manufacturer) - animal protein of cattle and Sunprotein vegetable protein.

Results and discussion. The obtained results indicate that the resulting dry powders can bring the finished product closer to a product with a balanced composition, high quality and nutritional value. It has been studied that specimens from the fillet of poultry, hams with skins, and meat of mechanical treatment of poultry contained more than $80-96 \%$ free moisture, which gives the product its use with greater juicy and tender consistency.

At the same time, the best water-retaining ability in the sample from the fillet of poultry is $10.2 \%$ and in Sunprotein $11.4 \%$. The greatest fat-retaining ability was the meat of mechanized treatment of poultry - $13.1 \%$ compared to the sample Mepro $85-5.25 \%$. The emulsifying ability in the sample meat of mechanical treatment of poultry is $73 \%$, which is 20 $25 \%$ higher compared to other samples.

As a result of microbiological research no bacteria of the colon germ, pathogenic microorganisms, including the genus Salmonella, sulfitreducing clostridia were found. The total amount of microorganisms after drying in all samples does not exceed the norm for boiled dried meat $5 \times 10^{3}$. The best result was observed in the sample Sunprotein $-1.8 \times 10^{3}$.

In the sensory analysis, it has been found that the sample of the fillet of poultry has a better outer look and smell, while the consistency is better in meat of mechanical treatment of poultry. It is the most crumbly, inherent in dry powders.

Conclusions. The comparative analysis confirms the high functional and technological properties of samples from the fillet of poultry and meat of mechanical treatment of poultry, as well as being safe for use in meat products. 


\section{Introduction}

The growing standard of living of the population in the conditions of deficiency of animal proteins has led to the intensive development of new trends in meat products, which consists in optimal combination of both meat and non-meal protein-containing food components for obtaining high-quality and biologically valuable foods. [9].

In the meat industry, animal and vegetable protein preparations are used not only as functional additives, which help increase the yield of traditional meat products, but also as the formulation components of combined meat products (milk protein preparations, soybean isolates, protein hydrolyzates, hydrocolloids etc.) [5].

Many scientists contributed significantly to the development of rational approaches to adequate replacement of meat raw materials with protein-containing and non-protein fillers, to improve the indicators of food and biological value and biological efficiency of meat products, their technological characteristics and cost-effectiveness [4]. They are: V.M. Pasychny, R. Tarte, E. Tornberg, P.A. Lofgren, A.I. Zharinov, N.A. Yancheva, M.M. Klimenko, A.Yu. Sokolova and other scientists [10].

Swedish scientist E. Tornberg was engaged in the development of milk protein preparations that had functional and technological properties similar to meat raw materials [2]. American scientist P.A. Lofgren was involved also in the development of milk protein preparations, namely casein sodium [3]. Such a technology has a limited range of applications, since there are people with lactose intolerance.

Arihara K. and Carballo J. were involved in the development of sausage products with the addition of dry meat powder. Campbell R. E., Hunt M. C. studied the methods of drying beef, but the disadvantage of their method is that the product was characterized by increased rigidity and low quality.

Taking into account that the proposed raw material, namely poultry meat, is a product that is rapidly spoiled, the production of a dry meat additive is promising to increase functionality, stability in storage and transportation. The use of modern technology helps to get products with a high content of high quality protein, high quality of products and nutritional value.

The development of technology of meat products with a dry meat additive is associated with the involvement of different types and grades of meat, as well as combining it with plant fillers, the development of innovative methods of drying and packaging products aimed at increasing the consumer properties and hygienic quality of products.

According to the results of previous studies, namely the use of different methods of meat drying (sublimation, infra-red, lyophilic, microwave-vacuum drying, drying with combined heat approach, etc.), it was established that one of the ways of preserving meat protein in the native state is drying at low temperatures, namely, the use of microwavevacuum drying [16]. Such drying leads to the release of a large amount of heat, which is spent solely on the evaporation of moisture without heating the fabric of the product, and as a result evaporation can occur at a low temperature [1]. This contributes to intensive evaporation of moisture without significant change in the structure of the surface layer, reducing the duration of processing, preservation of biologically active components of raw materials, dying of microbial cells and inactivation of enzymes.

The purpose of this research was to investigate the functional and technological properties of the received protein compositions from poultry meat and to determine the optimum with high quality indices. 


\section{Materials and methods}

\section{Materials}

The following objects of research were used: meat of mechanical treatment, fillet, hams with skins, which were subjected to microwave-vacuum drying. The following comparisons were used foreign counterparts Mepro 85 (the Dutch manufacturer) - animal protein from cattle and Sunprotein (USA) - vegetable protein. [16, 18]. The drying was carried out at a temperature of not more than $37^{\circ} \mathrm{C}$ to obtain the required mass of condensate at constant stirring [6].

\section{Determination of moisture content}

The moisture content of the protein component was determined by drying the crushed sample at a temperature of $150^{\circ} \mathrm{C}$ for 1 hour. The mass fraction was determined as the difference between the weight of the drying unit (A1) and after drying (B) to the weight of the weight gain (A), expressed as a percentage:

$$
\mathrm{W}=\left(\mathrm{A}_{1}-\mathrm{B}\right) / \mathrm{A} \times 100
$$

\section{Determination of the number of MAOAM}

Determination of mesophilic aerobic and optional anaerobic microorganisms was carried out using a deep sowing method based on seeding of product dilutions into a dense nutrient medium.

At $1 \mathrm{cc}$. From each breeding place are put on the bottom of two sterile Petri cups, slightly opening them. Then, in each cup, pour 15-20 cubic centimeter of molten and cooled to $45{ }^{\circ} \mathrm{C}$ of nutrient agar with yeast extract and glucose are poured, then the cup is stirred along the surface of the table with circular motions [10]. After cooling the agar, the cups are placed in the thermostat upside down at $30{ }^{\circ} \mathrm{C}$ for 72 hours. Then the calculation of all types of colonies is conducted.

\section{Drying process}

The studies were carried out in a sealed reactor of a radio-transparent material (glass). Vacuum in the chamber is provided by a membrane vacuum pump. The reactor is placed in a chamber with a microwave energy source. The vapor volume of the chamber was communicated with the condenser where cold water circulated. Steam was converted into condensate, and the mass of condensate was determined by means of digital scales [16]. The moisture content of the raw material was established by the mass of the condensate. The temperature of the reactor was measured with a radiation pyrometer, and the pressure in the chamber was measured with a vacuum gauge. The consumed electric energy was determined with the help of a meter.

\section{Determination of water-absorbing ability}

The water-binding ability of meat was determined by the Grau and Hamma method. A weight of the mass of $0.3 \mathrm{~g}$, weighed to $0.0001 \mathrm{~g}$ precision on a polyethylene with a 
diameter of 55-60 mm is transferred to an ash-free filter, which is placed on a Plexiglas plate $100 \times 100 \mathrm{~mm}$ in size. The hard cover is covered with another plate of the same size and a load of $1 \mathrm{~kg}$ is placed on top. The pressing lasts for 10 minutes, after which the contour marks the spots around the pressed meat. The area is measured by a planimeter in cubic centimetres. The content of bound water in meat is calculated by the formula:

$$
\mathrm{V}=(\mathrm{A}-\mathrm{K} \times \mathrm{B}) / \mathrm{M} \times 100
$$

A-water content in weight, $\mathrm{mg} ; \mathrm{K}=8.4 \mathrm{mg}$; B- area of a wet spot, $\mathrm{cm}^{2}$, M-the mass of weight meat, $\mathrm{mg}$.

\section{Determination of water-retaining capacity}

The protein component is hydrated in distilled water at a ratio of 1: 5 for 1 hour, then it is placed in a thermostat with a temperature of $74-76^{\circ} \mathrm{C}$ and kept for 15 minutes. The contents of the glasses are transferred to centrifuge nets and centrifuged for 15 minutes at $1000 \mathrm{rpm}$ for separation of unbound water. It is calculated as the difference between the mass of the hydrated texture (Mr) and the mass of dry (Ms) to the mass of dry texture (Ms), expressed as a percentage:

$$
\mathrm{WRA}=(\mathrm{Mr}-\mathrm{Mc}) / \mathrm{Mc} \times 100
$$

\section{Determination of fat-retaining ability}

The protein component is dispersed in $10 \mathrm{~g}$ of vegetable oil and for $1 \mathrm{~h}$ at $20^{\circ} \mathrm{C}$, then placed in a thermostat with a temperature of $74-76{ }^{\circ} \mathrm{C}$ and kept for 15 minutes. The contents of the glasses are transferred to centrifuge mesh and centrifuged for 15 minutes at $1000 \mathrm{rpm}$. Calculated as the difference between the mass of the dispersing texture (Mr) and the mass of dry (Ms) to the mass of the dry texture (Ms), expressed as a percentage:

$$
\mathrm{FRA}=(\mathrm{Mr}-\mathrm{Mc}) / \mathrm{Mc} \times 100
$$

\section{Results and discussion}

\section{Determination of microbiological indicators}

Experimental studies were conducted with dry protein concentrate on the following indicators: microbiological, physico-chemical and sensory [7, 8].

The first point of control is the determination of the sanitary state of the powder after its preparation.

Microbiological contamination of the samples was determined before and after drying (Figure 1). According to the results of the obtained data, it was determined that the total number of microorganisms after drying in all samples did not exceed the norm for boiled dried meat $5 \times 10^{3}$, as well as no bacteria of the colon germ, pathogenic microorganisms, including the genus Salmonella, sulfitreducing clostridia were found. That is, dry meat additives comply with standard, do not exceed the permissible level and are safe for use in meat products. 


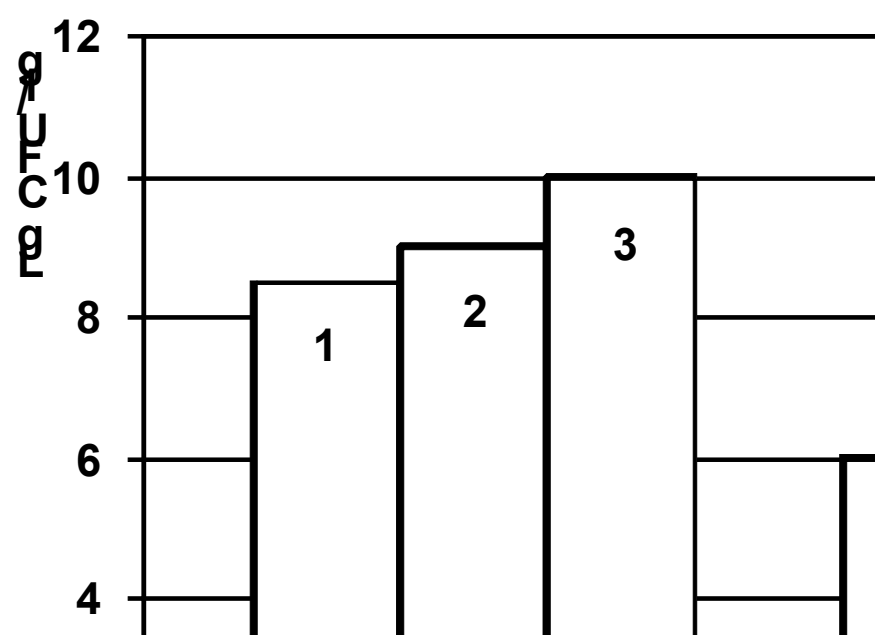

Figure 1. Lg colony-forming units/ $1 \mathrm{~g}$ protein component:

1 - Chicken Fillet, 2 - Chiken Ham, 3 - MMT, 4 - Sunprotein, 5 - Mepro 85, 6 Standard.

\section{Determination of functional and technological indicators}

The next stage of the research was the study of the functional and technological properties of all experimental samples namely: moisture content after drying, water-binding ability, water-retaining ability, fat-retaining ability and emulsion stability.

The result of determining the moisture content after drying in the samples studied is different, which is due to their composition and the effect of heat treatment in the drying stage, as well as the properties of raw materials [15].

At the mechanical action of high pressure on muscle fibers of poultry meat, there occurs a destruction of myofibrils with the release of myofibrillar proteins. This is accompanied by a rupture of electrostatic bonds and the formation of ionized groups that bind water [12].

On the basis of the data obtained, it can be concluded that the emergence of additional centers available in water after treatment by pressure, promotes the increase of moisture absorbing ability in poultry meat. 


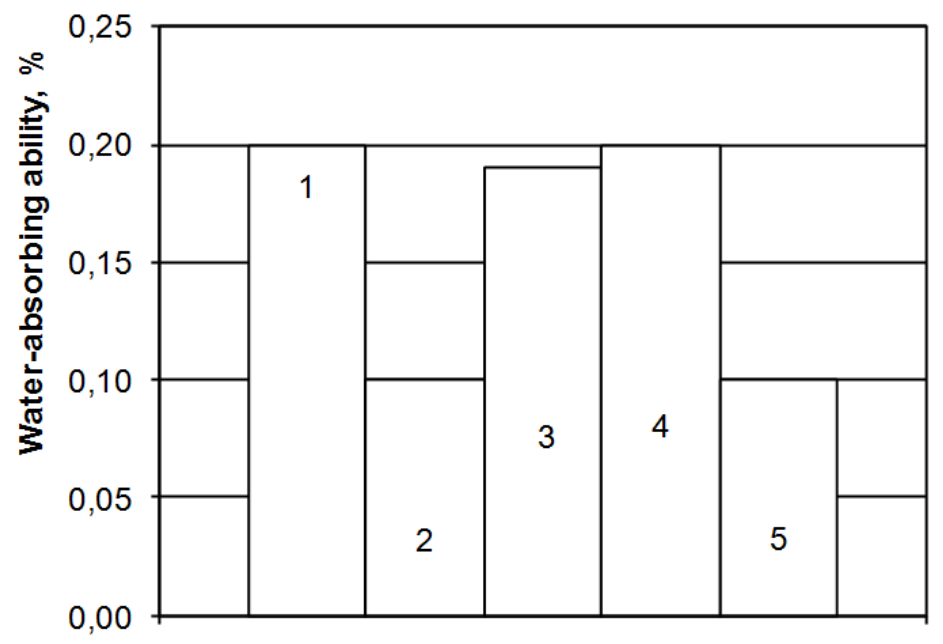

Figure 2. Moisture content of the protein component after drying: 1-Chicken Fillet, 2-Chiken Ham, 3-MMT, 4-Sunprotein, 5-Mepro 85.

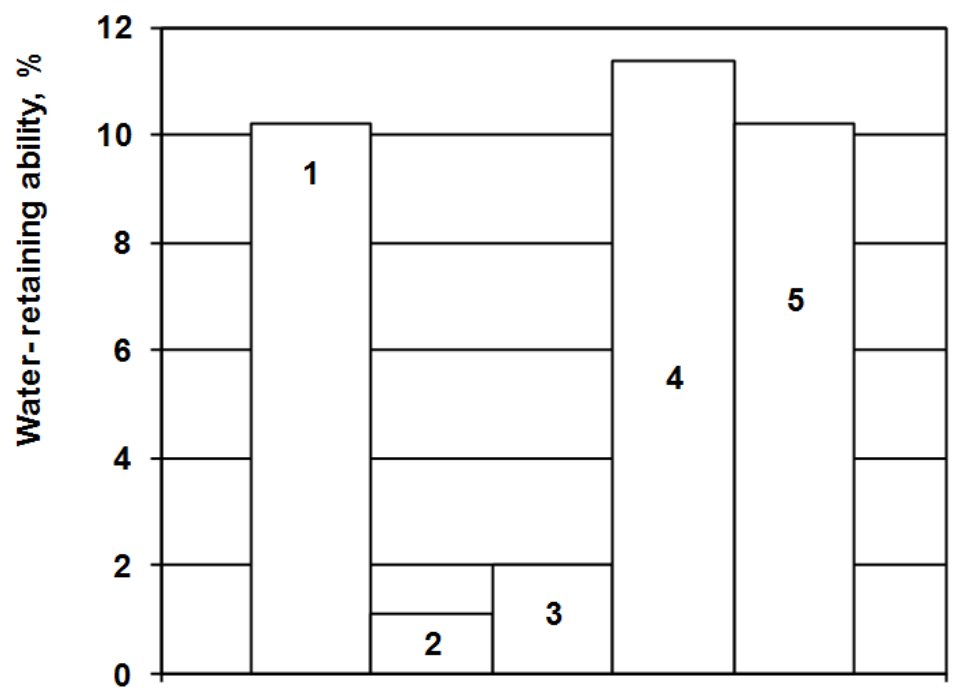

Figure 4. Content of water-retaining ability of the protein component after drying: 1 - Chicken Fillet, 2 - Chiken Ham, 3 - MMT, 4 - Sunprotein, 5 - Mepro 85. 


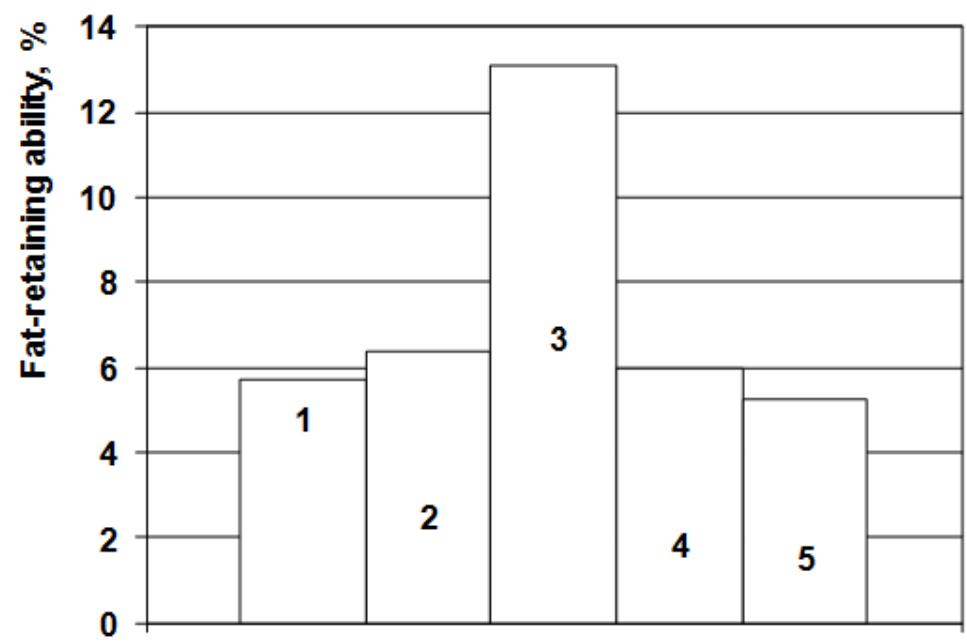

Figure 5. Content of fat - retaining ability of the protein component after drying: 1 - Chicken Fillet, 2 - Chiken Ham, 3 - MMT, 4 - Sunprotein, 5 - Mepro 85.

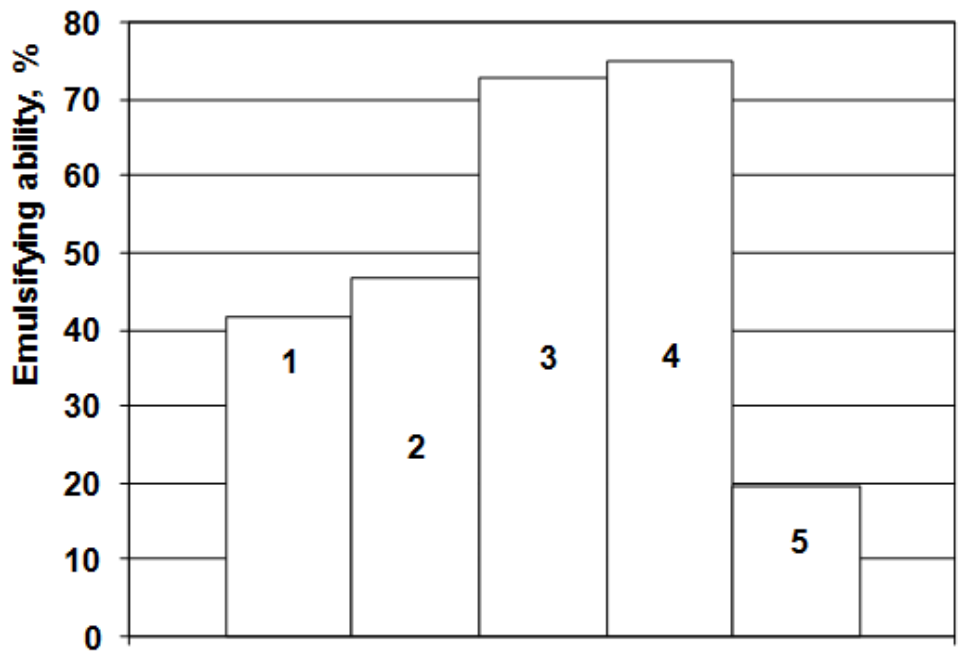

Figure 6. Content of emulsifying ability of the protein component after drying: 1 - Chicken Fillet, 2 - Chiken Ham, 3 - MMT, 4 - Sunprotein, 5 - Mepro 85.

The value of water-retaining, fat-retaining and emulsifying ability in the samples varies, due to their composition and the effect of heat treatment in the drying stage. Comparing all the studied samples of meat supplements studied as protein filler, we see that the highest results were found in chicken fillet and meat of mechanical processing, the lowest observed in chicken ham [14]. 


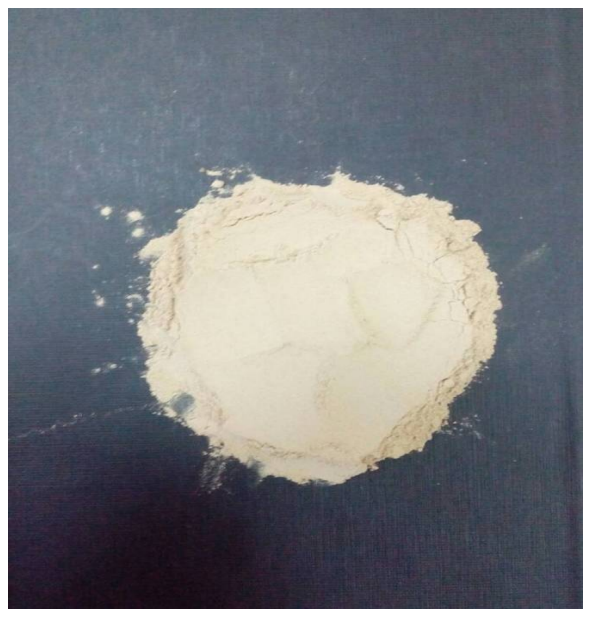

$a$

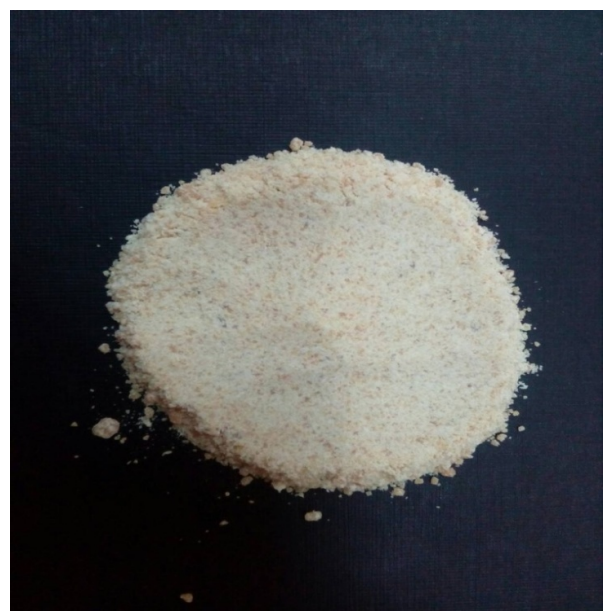

b

Figure 7. The samples of the protein component after drying: a- MMT, b- Sunprotein
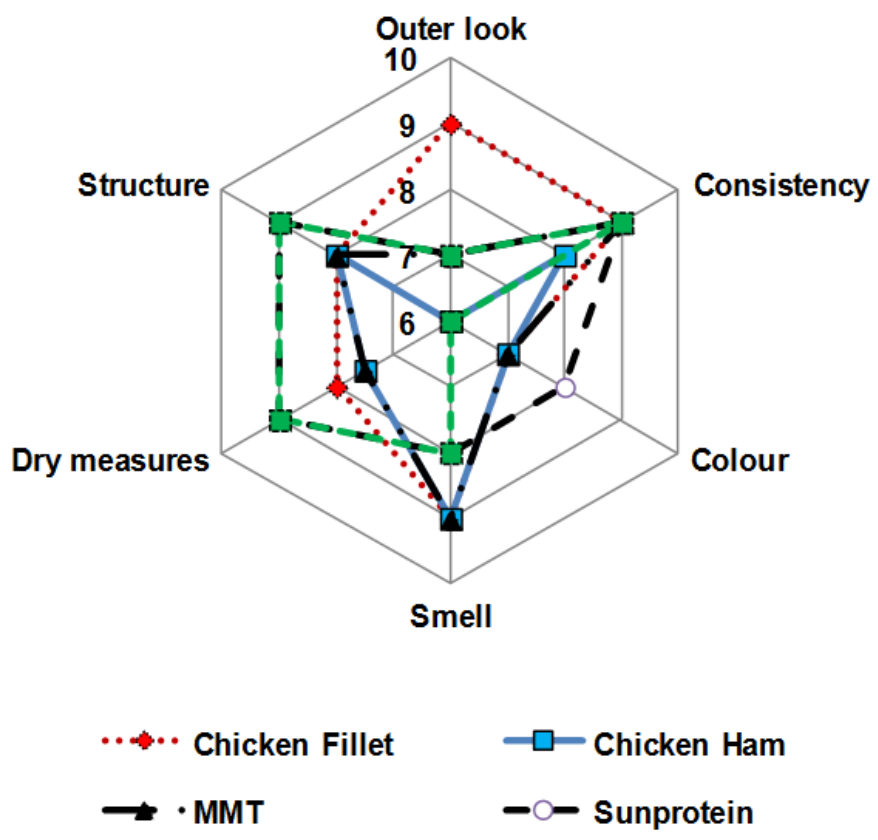

Figure 7. Profilogram of the studied meat additives 
According to the sensory evaluation, model meat supplements were characterized by high sensory characteristics [2]. Loose consistency, inherent in dry powders, homogeneous color, like meat, pleasant scent. The best sensory properties were found in chicken fillet, mechanical collapse meat and sunprotein, the lowest rates were observed in the chicken ham.

\section{Conclusion}

1. Based on the analysis of existing technologies for the production of protein supplements from various anatomical parts of poultry meat, the technology of dry additives with the use of electromagnetic energy sources of ultrahigh frequency under vacuum was developed.

2. In work was investigated of efficient use of meat additives in meat products is investigated, to compare different samples according to microbiological, physicalchemical and functional-technological indicators.

3. It is shown that the highest rates were observed in dry powders of chicken fillet and mechanically-processed meat, which will bring the finished product closer to a product with a balanced composition, high quality and nutritional value.

4. Based on the results obtained and from an economic point of view it is more appropriate to use dry powder from mechanical collapse meat.

5. It has been experimentally established that the protein composition of animal origin obtained by the proposed method meets the existing technological regulations.

Regulation EU No. 178/2002 requires enterprises to identify from whom raw materials and ingredients and have a traceability system and procedures that allow them to quickly obtain the necessary information. As a result, the use of the developed additive allows you to create meat products controlled by origin.

\section{References}

1. Alessandro Lana, Lello Zolla (2016), Proteolysis in meat tenderization from the point of view of each single protein: A proteomic perspective, Journal of Proteomics, 147, pp. 85-97.

2. Tornberg E. (2005), Effects of heat on meat proteins - Implications on structure and quality of meat products, Meat Science, 70(3), pp. 493-508.

3. Lofgren P.A. (2013), Meat, Poultry, and Meat Products: Nutritional Value, Reference Module in Biomedical Sciences, pp. 160-167.

4. Tarte R. (2011), Meat protein ingredients, Handbook of Food Proteins, pp. 56-91.

5. Hayes J., Brunton N. (2011), The use of nutraceuticals in processed meat products and their effects on product quality, safety and acceptability, Processed Meats: Improving Safety, Nutrition and Quality, pp. 372-402.

6. Pattra Laopoolkit, Prisana Suwannaporn (2011), Effect of pretreatments and vacuum drying on instant dried pork process optimization, Meat Science, 88(3), pp. 553-558.

7. Dolores Garrido, Macarena Egea, Belen Linares, etc., (2017), Sensory characteristics of meat and meat products from entire male pigs, Meat Science, 129, pp. 50-53.

8. Benjamin M., (2017), Review: Nutrient density and nutritional value of meat products and non-meat foods high in protein, Trends in Food Science \& Technology, 65, pp.103-112. 
9. Vinnikova L.G. (2006), Tekhnologiia miasa i miasoproduktov, Firma «Inkos», Kyiv.

10. Antipova L.V. (2001), Metody issledovaniia miasa i miasnykh produktov, Kolos, Moscow.

11. Polianskaia S.V. (2013), Kompleksnyi podkhod $k$ pererabotke ptitsy, Miasnaia industriia, Moscow.

12. Probst Y. (2009), Nutrient Composition of Chicken Meat, Rural Industries Research and Development Corporation, Australia, p.75.

13. Pasichnyi V.N. (2004), Tekhnologiia proizvodstva gidratirovannykh beloksoderzhashchikh napolnitelei farshevykh sistem, Miasnoi biznes, 7, pp. 18-21.

14. Pasichnyi V.N. (2004), Tekhnologiia proizvodstva gidratirovannykh beloksoderzhashchikh napolnitelei farshevykh sistem, Miasnoi biznes, № 8, pp. 1215 .

15. Donskova L.A. (2004), Pishchevye dobavki v miasnoi industrii: identifikatsiia opasnostei i skriningovyi analiz riska, Upravlene, 3, p. 49.

16. Burdo O.G., Burdo A.K., Sirotyuk I.V., Pour D.R. (2017), Technologies of Selective Energy Supply at Evaporation of Food Solutes, Regional Energetic Problems, Kishinev, 1(33), p.100.

17. Gizburg A.S. (1973), Osnovy teorii i tekhniki sushki pishchevykh produktov, Pishchevaia promyshlennost, Moscow, p. 527.

18. Stankevich G.N. (2006), Raschet prodolzhitelnosti sushki po uravneniiam kinetiki s uchetom konstruktivnykh osobennostei sushilok, Naukovi pratsi ONAPT, 28(2), pp. $14-20$. 